\title{
DETERMINATION OF FRUIT DEVELOPMENT STAGES AND PRODUCTION OF DATES IN KHAIRPUR SINDH PAKISTAN
}

\author{
Dr. Muhammad Mahmood-Ur-Rahman Jamro \\ Principal Scientific Officer \\ Pakistan Agricultural Research Council \\ Arid Zone Research Institute Technology Field Station Khairpur, Sindh, Pakistan \\ E-mail:mrjamro@yahoo.com \\ Dr. Zulfiqar Ali Abbasi \\ Assistant Professor \\ Shaheed Zulfiqar Ali Bhutto Agriculture College Dokri \\ Larkana, Sindh, Pakistan \\ E-mail: zaabbasi786@gmail.com \\ Dr. Ali Sher Chandio \\ Principal Scientific Officer \\ Pakistan Agricultural Research Council-Southern Zone Agricultural Research Centre \\ Karachi, Sindh, Pakistan \\ E-mail: azam.parc@gmail.com
}

\begin{abstract}
The study was conducted to record fruit development stages of nine Date palm cultivars from spathe initiation to harvest. The data was recorded as per each parameter; finally mean days were calculated at completion of each fruit development stage. The results revealed that all cultivars initiated spathes from $8^{\text {th }}$ January to $26^{\text {th }}$ February. Significant differences were recorded in all physiological fruit development stages. The minimum period of (13.66 days) and maximum (24.00 days) were taken by Shakri and Begum jangi respectively up to the spathe maturity stage, whereas Aseel taken (14.33 days) and Dhaki recorded (27.00 days) to pollination. In the fruit setting (Hababuk stage) Hussaini noted minimum period of (44.33 days) and Muzawati observed maximum (57.66 days). In Doka formation (Kimri stage, the Hussaini cultivar recorded lowest period of (71.33 days) and Muzawati taken highest (99.33 days). Up to mature fruit (khalal stage) Begum jangi attained the minimum (110.33 days). However Fasli and Dhakki observed the maximum (153.67 days). At Rutab stage, the cultivar Begum jangi recorded lowest harvesting period (118.33 days) and Dhaki noted highest (158.00 days). In relation to the maximum yield Dhaki recoded $(169.00 \mathrm{~kg} / \mathrm{plant})$ and Hussaini produced minimum yield $(97.00 \mathrm{~kg} /$ plant $)$.
\end{abstract}

Keywords: Date Palm, Fruit Stages, Production, Varieties.

\section{INTRODUCTION}

Female plant of Date palm (Phoenix dactylifera L.) bears fruit once a year; mostly it is consumed in fresh, dried and in different ways. It is one seeded oblong berry varying in ovate, obovate, spherical, elliptical, cylindrical shape (Markhand et al., 2010) with the terminal stigma, fleshy pericarp and a membranous endocarp. Dates are classified into soft, semi soft, dry and semi dry according to harvest time (Chao \& Krueger, 2007). Generally Dates take about 6-7 months from spathe emergence to fully ripened. Fruit formation starts after the 
application of pollens by hand or mechanical ways. One male plant is sufficient for pollination to fifty female plants. The pollen flowers are cut from the male tree and applied to the female blooms when spathe of female plant cracks naturally which means that, it is ready for pollination. After removing of a hard cover around the spathe, a cluster of flowers is inserted into female inflorescence to assure fruit set. For successful pollination, high potent pollen source plays a significant role (Benmehaia \& Baka, 2015). The pollination efficacy depends on the pollination time, flowering period of male, viability, quantity and female flower receptivity. Awad and Qureshi (2012) reported that pollen affects directly on the receptiveness of female flower. Abbas et al. (2012) also observed differences in female flower receptivity. Satisfactory pollination results can be obtained within two or four days after spathe opening. Five growth and development stages of dates are considered. Among them the Hababouk is an earliest stage of fruit, it is also called "baby fruit" which starts after fertilization and lasts for 4-5 weeks by the loss of two unfertilized carpals. During that period fruit weighs up to one gram with 85 to $90 \%$ moisture (Fadel et al., 2006). After that second phase of fruit growth appears in 17 weeks subsequent to fertilization, depending upon location and cultivar. This segment is categorized also in two stages. In first period the dimension and mass of fruit quickly increase with additional sugar and water, whereas in second phase, weight, acidity and sugar occur with higher water (Fallahi, 1996). In Tamar stage, fruit changes the color and attaining softness (Myhara et al., 1999). Generally due to availability of lesser water and greater amount of sugar; fruit of this stage is mostly stored (Hong et al., 2006; Awad, 2007). In Sindh, monsoon rains during the months of July and August, these are peak production periods of Date palm. Even for the short duration, rainfall extremely harmful and causes heavy fruit loss. Therefore, the study was conducted to examine the fruit development stages as Date palm cultivars can be categorized according to their maturity period.

\section{MATERIALS AND METHODS}

Nine Date palm cultivars specifically Shakri, Fasli, Karbalain, Aseel, Dhaki, Hussaini, Eidal Shah, Muzawati and Begum jangi were selected for study which were already grown in the field of Date Palm Research Station Kot Diji, Khairpur, Sindh, Pakistan. During the fruiting season of 2018 and 2019, plants were selected, based upon age uniformity (10 - 15 years old), they were free of insects' damage and diseases. Five plants from each cultivar were selected and kept under the regular schedule of cultural practices. The experiment was carried out under completely randomized design with three replications. The data for different parameters i.e. Date of spathe initiation, Days taken to spathe maturity, Days taken to pollination, Days taken to fruit setting (Hababuk stage, Days taken to Doka formation (Kimri stage, Days taken to Dang formation (Rutab stage), Days taken to harvest, yield/plant (Kg). The collected data analyzed for analysis of variance (ANOVA) using a Statistix version 8.1 software technique (Statistix, 2006). The least significant difference test (LSD) was used at alpha 0.05 for comparing differences of treatments.

Table 1. Fruit development stages and yield of Date palm cultivars during crop season 2018 and 2019

\begin{tabular}{|c|c|c|c|c|c|c|c|c|c|}
\hline S.No & $\begin{array}{l}\text { Name of } \\
\text { cultivar }\end{array}$ & $\begin{array}{c}\text { Date of } \\
\text { spathe } \\
\text { initiation }\end{array}$ & $\begin{array}{l}\text { Days taken } \\
\text { to spathe } \\
\text { maturity }\end{array}$ & \begin{tabular}{|c|} 
Days taken to \\
pollination
\end{tabular} & $\begin{array}{c}\text { Days taken to } \\
\text { fruit setting } \\
\text { (Hababuk } \\
\text { stage) }\end{array}$ & $\begin{array}{l}\text { Days taken to } \\
\text { immature } \\
\text { Doka formation } \\
\text { (Kimri stage) }\end{array}$ & $\begin{array}{c}\text { Days taken to } \\
\text { mature Doka } \\
\text { formation } \\
\text { (Khalal stage), }\end{array}$ & $\begin{array}{c}\text { Days taken to } \\
\text { Harvesting } \\
\text { (Dang } \\
\text { formation } \\
\text { Rutab stage) }\end{array}$ & $\begin{array}{c}\text { yield/plant } \\
\text { (Kg) } \\
\text { (Rutab } \\
\text { stage) }\end{array}$ \\
\hline 1 & Shakri & $\begin{array}{c}20-26 \\
\text { January }\end{array}$ & $13.66 \mathrm{c}$ & $21.66 \mathrm{bc}$ & $47.33 \mathrm{bc}$ & $81.00 \mathrm{de}$ & $135.33 \mathrm{c}$ & $142.67 \mathrm{e}$ & $156.33 \mathrm{ab}$ \\
\hline 2 & Fasli & $\begin{array}{c}25-31 \\
\text { January }\end{array}$ & 19.00abc & $22.33 b$ & $49.00 \mathrm{~b}$ & $87.33 b c$ & $153.67 \mathrm{a}$ & $157.67 \mathrm{ab}$ & 148.00abc \\
\hline
\end{tabular}




\begin{tabular}{|c|c|c|c|c|c|c|c|c|c|}
\hline 3 & Karbalain & $\begin{array}{c}08-14 \\
\text { February }\end{array}$ & $17.00 \mathrm{bc}$ & $18.33 \mathrm{~d}$ & $46.00 \mathrm{bc}$ & $76.00 \mathrm{ef}$ & $147.33 b$ & $155.67 \mathrm{ab}$ & $150.67 \mathrm{ab}$ \\
\hline 4 & Aseel & $\begin{array}{c}10-16 \\
\text { February }\end{array}$ & $14.00 \mathrm{c}$ & $14.33 \mathrm{e}$ & $48.33 b$ & $82.66 \mathrm{~cd}$ & $147.67 b$ & $153.00 \mathrm{bc}$ & $109.67 b c$ \\
\hline 5 & Dhaki & $\begin{array}{l}09-15 \\
\text { February }\end{array}$ & $21.33 \mathrm{ab}$ & $27.00 \mathrm{a}$ & $54.66 \mathrm{a}$ & $88.33 b$ & $153.67 \mathrm{a}$ & $158.00 \mathrm{a}$ & $169.00 \mathrm{a}$ \\
\hline 6 & Hussaini & $\begin{array}{c}06-12 \\
\text { February }\end{array}$ & $20.33 \mathrm{ab}$ & 24.00ab & $44.33 c$ & $71.33 \mathrm{f}$ & $128.33 \mathrm{e}$ & $149.67 \mathrm{~cd}$ & $97.000 \mathrm{c}$ \\
\hline 7 & Eidal Shah & $\begin{array}{c}12-18 \\
\text { February }\end{array}$ & $16.66 \mathrm{bc}$ & $17.66 \mathrm{~d}$ & $45.66 b c$ & 77.33de & $133.67 \mathrm{~cd}$ & $145.00 \mathrm{de}$ & $107.67 \mathrm{bc}$ \\
\hline 8 & Muzawati & $\begin{array}{c}13-19 \\
\text { February }\end{array}$ & $19.00 \mathrm{abc}$ & $22.00 \mathrm{bc}$ & $57.66 a$ & $99.33 \mathrm{a}$ & $131.33 \mathrm{de}$ & $141.33 \mathrm{e}$ & $146.67 \mathrm{abc}$ \\
\hline 9 & $\begin{array}{l}\text { Begum } \\
\text { jangi }\end{array}$ & $\begin{array}{c}20-26 \\
\text { February }\end{array}$ & $24.00 \mathrm{a}$ & $26.33 a$ & $44.66 \mathrm{c}$ & $97.33 \mathrm{a}$ & $110.33 f$ & $118.33 \mathrm{f}$ & $130.33 \mathrm{abc}$ \\
\hline \multicolumn{3}{|c|}{$\mathrm{CV}$} & 5.67 & 3.18 & 3.44 & 5.34 & 3.61 & 4.918 & 51.33 \\
\hline
\end{tabular}

In each column means followed by common letter are not significantly different at $5 \%$ probability level.

\section{RESULT AND DISCUSSION}

Results of the study presented in (Table 1) revealed that among the cultivars, each fruit development stage differed significantly. The spathe emergence initiated from $20^{\text {th }}$ January to $26^{\text {th }}$ February during both seasons. Shakri and Fasli cultivars found earlier in the spathe emergence. However cultivar, Begum jangi observed late (fourth, week) of February. These months are considered as very suitable for spathe emergence in Sindh due to low temperature. The Begum jangi and Dhakki cultivars recorded maximum (24.00, 20.33 days) spathe maturity period respectively. Whereas Shakri cultivar taken the minimum period of (13.66 days) accordingly. The variation in spathe maturation depends on the variety, environmental conditions and management practices (Zaid \& Wet, 2002; Al-Yahyai \& Al-Kharusi, 2012).

Due to dioeciously nature of Date palm, pollination is considered a significant factor which affects fruit set, yield and fruit quality. The period of receptivity differs with diverse weather factors and cultivars (Shaheen, 1986; Marzouk et al., 2002a). In this study Dhakki taken maximum (27.00 days) to pollination, after spathe initiation followed by $(26.33,24.00$, 22.33, 22.00, 21.66, 18.33, 17.66 and 14.33) Begum jangi, Hussaini, Fasli, Muzawati, Shakri, Karbalain, Eidal shah and Aseel respectively. After spathe maturity male pollens were applied within 2-7 days according to the opening of Spathe. These results are supported by (El-Kassas \& Mahmoud, 1984; El-Salhy et al., 2011) they reported that after spathe cracking optimum period for female flower accessibility considered within three to four days. But according to the previous studies scientists reported that, this period could be extended up to 5 days (Ahmed \& Shaikh, 1971) seven days (Gupta \& Thatai, 1980) seven-twelve days (Stoler, 1972) eightten days (Pereau-Leroy, 1957) nine days (Al-Bajallani et al., 1989) ten days. After pollination four to seven days are considered for high fruit quality and yield (Marzouk et al., 2002b; AlWasfy 2005; Samih, 2006; Moustafa, 1998; Dammas, 1998). Delaying pollination significantly reduce fruit set, fruit retention; consequently bunch weight reduction as compared to immediate pollinated female spathe.

Hababouk is the earliest stage of fruit development which occurs by the loss of two unfertilized carpels. Since date of spathe initiation, the maximum days (57.66) by Muzawati followed by Dhakki (54.66), Fasli (49.00), Aseel (48.33), Shakri (47.33), Karbalain (46.00), Eidal shah (45.66), Begum jangi (44.66) and Hussaini (44.33) were recorded. The disparity in days taken to the fruit set may be accredited to genetic characters of pollen source. These findings are also in close agreement with the results of Iqbal et al. (2012) who observed that source of pollen has a significant effect on days to the fruit setting in date palm. The maximum (99) days in cultivar Muzawati followed by Begum jangi (97.33), Dhakki (88), Fasli (87.33), 
Aseel (82.66), Shakri (81.00), Eidal shah (77.33), Karbalain (76.00) and Hussaini (71.33) were noted at Kimri stage (immature green stage). Variation in days to Kimri stagte might be due to variety and location.

Fasli and Dhakki cultivars recorded, the maximum (153.67) days followed by 147.33, 135.33, 133.67, 131.33 and 110.33 by Karbalain and Aseel, Shakri, Eidal shah, Muzawati and Begum jangi respectively in Khalal (mature stage) since spathe initiation. The speedy fruit growth from kimri to khalal stage is mostly due to the quick cell division and process of elongation. These results are generally in agreement with past reports of (Bacha et al., 1987; Al-Qurashi, 2010). It was also noticed that fruit growth characters increased progressively as fruit matures and growth seizes after reaching Khalal (colored stage) (Awad et al., 2011; AlHootie et al., 1997) also established these results.

The studied cultivars were harvested on Rutab stage. The maximum 158.00 days since spathe initiation to harvesting were recorded by Dhakki cultivar, whereas minimum 118.33 days, for the same stage was recorded by cultivar Begum jangi. However, other varieties Fasli, Karbalain, Aseel, Hussaini, Eidal shah, Shakri and Muzawati recorded 157.67, 155.67, 153.00, $149.67,145.00,142.67$ and 141.33 days since spathe initiation to harvesting respectively. It is noticed that Dhakki cultivar taken maximum duration up to Tamar stage due to its larger size of fruit. These results are in agreement with the conclusion of Al-Khalifah (2006) who concluded that the pollen source had considerable effect on fruit maturity.

The cultivar Dhakki produced highest fruit yield (169 kg/plant) at the Rutab stage, whereas Shakri, Karbalain, Fasli, Muzawati, Begum jangi, Aseel, Eidal shah and Hussaini produced 156.33, 150.67, 148.00, 146.67, 130.33, 109.67, 107.67 and $97.00 \mathrm{~kg} / \mathrm{plant}$ respectively. The results indicated that Dhakki cultivar recorded maximum yield which is due to higher fruit setting, fruit weight, size and high moisture content.

As per key objective of this study when the results were compared on the basis of harvesting period, it was noted that Begum jangi and Shakri cultivars were harvested during the last week of June. Muzawati, Hussaini and Fasli were harvested in the first week of July. Aseel, Karbalain, Eidal shah in the second week of July and Dhakki was harvested during the fourth week of July.

\section{CONCLUSION}

From the results of this study it can be concluded that except Begum jangi and Shakri which are still not considered commercial Dates; other cultivars falls in the monsoon period. Therefore, protection measures from rain and availability of other varieties for this province is suggested as the Dates sector of Sindh can be secured for future consumption and trade.

\section{ACKNOWLEDGEMENT}

Authors gratefully acknowledge Mr. Zakir Hussain Mahessar, Director Date palm research station Kot Diji, Khairpur, Sindh, Pakistan for provision of research facilities throughout the study.

\section{REFERENCES}

Abbas, M. F., Abdulwahid, A. H., \& Abass, K. I. (2012). Effect of pollen parent on certain aspects of fruit development of Hillawi date palm (Phoenix dactylifera L.) in relation to levels of endogenous gibberellins. Advances in Agriculture \& Botanics, 4(2), 42-47.

Al-Qurashi, A. D. (2010). Physico-chemical changes during development and ripening of' Helali'date palm fruit. Journal of Food, Agriculture \& Environment, 8(2), 404-408. 
Ahmed, S., \& El-Shaikh, H.M. (1971). Receptivity of pistilite flowers in date palm. Punjab Frt. J. Lyallur, Pakistan, pp: 34242.

Al-Bajallani, A. N. R., Al-Attar, A., \& Mohammad, A. A. (1989). Effect of day-time pollination during ten days aftere spth spalitting on fruit setting of Phoenix dactylifera L. cv. sukkari. Annals of Agricultural Science (Egypt).

Al-Hooti, S., Sidhu, J. S., \& Qabazard, H. (1997). Physicochemical characteristics of five date fruit cultivars grown in the United Arab Emirates. Plant Foods for Human Nutrition, 50(2), 101-113.

Al-Khalifah, N. S. (2006). Metaxenia: influence of pollen on the maternal tissue of fruits of two cultivars of date palm (Phoenix dactylifera L.). Bangladesh J. Bot, 35(2), 151-161.

Al-Yahyai, R., \& Al-Kharusi, L. (2012). Physical and chemical quality attributes of freezestored dates. International Journal of Agriculture and Biology, 14(1).

Al-Wasfy, M. M. (2005, April). Studies on receptivity of pistillate flowers of Zaghloul and Haiany date palm cultivars under Qena conditions. In Proceeding of Second Syrian Egyptian Conf (pp. 25-28).

Awad, M. A., \& Al-Qurashi, A. D. (2012). Partial fruit set failure phenomenon in 'NabbutAli' and 'Sabbaka'date palm cultivars under hot arid climate as affected by pollinator type and pollination method. Scientia horticulturae, 135, 157-163.

Awad, M. A. (2007). Increasing the rate of ripening of date palm fruit (Phoenix dactylifera L.) cv. Helali by preharvest and postharvest treatments. Postharvest Biology and Technology, 43(1), 121-127.

Awad, M. A., Al-Qurashi, A. D., \& Mohamed, S. A. (2011). Biochemical changes in fruit of an early and a late date palm cultivar during development and ripening. International Journal of Fruit Science, 11(2), 167-183.

Benmehaia, R., \& Baka, M. (2015). Evaluation of male palms used in pollination and the extent of its relationship with cultivars of date-palms (Phoenix dactylifera L.) grown in region of Oued Righ, Algeria. Pak. J. Bot, 47(5), 2295-2300.

Bacha, M. A., Nasr, T. A., \& Shaheen, M. A. (1987). Changes in Physical and chemical characteristics of the fruits of four date palm cultivars. Proc Saudi Biol Soc, 10, 285295.

Chao, C. T., \& Krueger, R. R. (2007). The date palm (Phoenix dactylifera L.): overview of biology, uses, and cultivation. HortScience, 42(5), 1077-1082.

Dammas, M. O. (1998). Fruit growth and receptivity of pistillate flowers pollination in two date palm cultivars (Phoenix dactylifera L.) (Doctoral dissertation, M. Sc. Thesis, Fac. of Meteorology, Environment and Arid land Agri. King Abdel Aziz Univ). 
El-Salhy, A., Abdel-Galil, H. A., El-Akkad, M. M., \& Diab, Y. M. (2011). Effect of delaying pollination on yield and fruit quality of sewy date palm under new valley conditions in Egypt. Research Journal of Agriculture and Biological Sciences, 7(6), 408-412.

El-Kassas, S. E., \& Mahmoud, H. M. (1984). Receptivity of pistillate flowers of Zagloul date palm grown in upper Egypt. Assiut Journal of Agricultural Sciences (Egypt).

Fadel, M., Kurmestegy, L., Rashed, M., \& Rashed, Z. (2006). Fruit color properties of different cultivars of dates (Phoenix dactylifera, L.). Agricultural Engineering International: CIGR Journal.

Fallahi, M. (1996). Growth, Treatment, and Packaging of Date; Barsava Publication: Tehran, Iran, P. 124.

Gupta, M. R., \& Thatai, S. K. (1980). Receptivity of pistillate flowers in date-palm cv. Shamran. Journal of Research-Punjab Agricultural University, 17(4), 366-368.

Hong, Y. J., Tomas-Barberan, F. A., Kader, A. A., \& Mitchell, A. E. (2006). The flavonoid glycosides and procyanidin composition of Deglet Noor dates (Phoenix dactylifera). Journal of agricultural and food chemistry, 54(6), 2405-2411.

Iqbal, M., Niamatullah, M., \& Munir, M. (2012). Effect of various Dactylifera males pollinizer on pomological traits and economical yield index of cv's Shakri, Zahidi and Dhakki date palm (Phoenix dactylifera L.). The Journal of Animal \& Plant Sciences, 22(2), 376-383.

Markhand, G. S., Abul-Soad, A. A., Mirbahar, A. A., \& Kanhar, N. A. (2010). Fruit characterization of Pakistani dates. Pak. J. Bot, 42(6), 3715-3722.

Marzouk, H. M., El-Salhy, A. M., \& Hassan, R. A. (2002a). Effect of pollination on fruit set yield and fruit quality of Zaghloul and Samany date palm cultivars. A- Evaluation of five seedling date palm males and their effect on yield and fruit quality. In Proc. of Minia 1st Conference for Agriculture and Environmental Science, Minia, Egypt (pp. 983-997).

Marzouk, H. M., El-Salhy, A. M., \& Hassan, R. A. (2002b). Effect of pollination on fruit set, yield and fruits quality of Zaghlool and Samany date palm cultivars. B- Effect of male type and receptivity of pistillate flowers on fruit set, yield and some physical fruit properties. Proc. Minia 1st Conf. for Agric. And Environ. Sci. Minia, Egypt, (pp. 9991012).

Myhara, R. M., Karkalas, J., \& Taylor, M. S. (1999). The composition of maturing Omani dates. Journal of the Science of Food and Agriculture, 79(11), 1345-1350.

Moustafa, A. (1998, March). Studies on pollination of date palms. In Proceeding of the First International Conference on Date Palms, United Arab Emirates Univ., Al-Ain (pp. 3948).

Pereau-Leroy, P. (1957). Flower fertilization in date palm. Hort. Abst., 27(3), 2812. 
Samih, M. (2006). Determination of the best pollination time of sayer date cultivar. In Abstract of the Third International Date Palm Conf. Feb (Vol. 19).

Shaheen, M. A. (1986, September). Pistil receptivity in three cultivars of date palm (Phoenix dactylifera L.). In Proc. 1 Hot. Sci. Conf. st Tanta Univ. Egypt. September (Vol. 11, pp. 489-499).

Statistix. (2006). Statistix 8 user guide, version 1.0. Analytical Software, PO Box 12185, Tallahassee FL 32317 USA.Copyright (C 2006 by Analytical Software

Stoler, S. (1972). Date pollination and fertilization. II-Fertilization. Hort. Abst, 42(2), 4905.

Zaid, A., \& Wet, P.F. (2002). Botanical and systematic description of the date palm. In: Zaid A, Arias-Jim'enez EJ, editors. Date Palm Cultivation. Rome, Italy: FAO Plant Production and Protection Paper 156.

\section{Copyrights}

Copyright for this article is retained by the author(s), with first publication rights granted to the journal. This is an open-access article distributed under the terms and conditions of the Creative Commons Attribution license (http://creativecommons.org/licenses/by/4.0/) 